\title{
Dies irae
}

Tómas frá Celano (Tommaso da Celano) var ítalskur betlimunkur 1 á 13. öld (f. um 1185 eða 1190, d. 1260). Tómas óx upp í Celano á Mið-Ítalíu (bá í ríki Sikileyjarkonunga), hlaut klerklega menntun, kynntist heilögum Frans frá Assisi og tilheyrði betlimunkareglu hans frá pví hún var formlega stofnuð 1215. Tómas stýrði um skeið útbreiðslustarfi reglunnar á Pýskalandi. Hann samdi dýrlings-ævisögu heilags Frans (í premur gerðum), sömuleiðis heilagrar Klöru frá Assisi. Honum er einnig eignaður kirkjulegur kveðskapur á latínu, par á meðal Dies irae, sem pó er ekki á afgerandi rökum reist.

Dies irae, dies illa

solvet saeclum in favilla, teste David cum Sibylla.

Quantus tremor est futurus, quando judex est venturus, cuncta stricte discussurus!

Tuba mirum spargens sonum per sepulchra regionum, coget omnes ante thronum.

Mors stupebit et natura, cum resurget creatura, judicanti responsura.
Heiftardaginn hinst á láđi heimur ferst í sindurs brádi. pessu dís með Davío spáđi.

Skjálfandi má skepnan bíða: Skaparinn í málum lýda dag pann fellir dóminn stríða.

Lúður yfir gröfum gjalla Guð mun láta og par með alla fyrir hástól herrans kalla.

Dauðinn glúpnar, dignar, stríðir: Dómsstefnunni skepnan hlýðir, upp svo rísa allir lýdir. 
Liber scriptus proferetur, in quo totum continetur, unde mundus judicetur.

Judex ergo cum sedebit, quidquid latet apparebit: nil inultum remanebit.

Quid sum miser tunc dicturus? Quem patronum rogaturus, cum vix justus sit securus?

Rex tremendae majestatis, qui salvandos slavas gratis, salva me, fons pietatis.

Recordare, Jesu pie, quod sum causa tuae viae: ne me perdas illa die.

Quaerens me, sedisti lassus; redemisti crucem passus: tantus labor non sit cassus.

Juste judex ultionis, donum fac remissionis, ante diem rationis.

Ingemisco, tamquam reus. Culpa rubet vultus meus. Supplicanti parce Deus.

Qui Mariam absolvisti, et latronem exaudisti, mihi quoque spem dedisti.
Eina bók, sem allt hið sanna á finnst ritað, skal hér kanna svo að dæmist syndir manna.

Pegar Drottinn dóma vekur dylst ei lengur hver er sekur; straffi ekkert undan tekur.

Hvert má nú í skjólið skrî̉a skálkur minn, án hjálpar lýða, bestu menn ef böli kvíða?

Ægikóngur himni hærri huggar præla miskunn skærri. Ver mér, brunnur náðar, nærri.

Hafðu, Jesú minn, í minni mig, sem naut af jarðvist pinni, hinsta dag að frelsið finni.

Bið ég ei til einskis pyldi efstu píslir herrann mildi pegar mér hann vægja vildi.

Nær að skuldadögum dregur, dómarinn minn vegsamlegur, upp gef sök að opnist vegur.

Fyrir dómi sökum seldur; syndin dómsáfelli veldur nema Guð mín gæti heldur.

Magdalena sýkn varð saka, sáttum ránsmanns vannstu taka. Einnig mér lést vonir vaka. 
Preces meae non sunt dignae, Enga vissu bænir boða: sed tu bonus fac benigne: ne perenni cremer igne.

Inter oves locum praesta, et $\mathrm{ab}$ headis me sequestra, statuens in parte dextra.

Confutatis maledictis flammis acribus addictis, voca me cum benedictis.

Oro supplex et acclinis, cor contritum quasi cinis. Gere curam mei finis.

Lacrimosa dies illa, qua resurget ex favilla, judicandus homo reus; huic ergo parce Deus.

Pie Jesu Domine, dona eis requiem.
Bið ég pína gæsku stoða eilífum gegn eldsins voða.

Pér á hægri hönd án nauða, höfrum fjarri merktum dauða, finn mér stað í flokki sauða.

Fordæmdir pá feigðarhnífsins finna brodd í logum kífsins, kalla mig til ljóss og lífsins!

Dreyrgu hjarta í duftið hneigi. Drottinn sæll ég bið að megi annast mig á efsta degi.

Dagur óps og ekkasoga upp pá rís af sindurs loga, maður fyrir dóm skal dreginn. Drottinn bendi á náđar veginn.

Sælan Jesúm bljúgur bið: Gef peim nád að finni frið. 


\section{Um pýðinguna}

Tatínutextinn er messusálmur eða sekvensa, oftast eignaður Assisi, og pá ortur um eða skömmu fyrir $1250 .{ }^{1}$ Handritum eða lesbrigðum kann ég ekki skil á en hér er fylgt pví orðalagi ${ }^{2}$ sem lengst af var haftí sálumessuritúali kapólsku kirkjunnar og par með líka í sálumessum tónskáldanna, Mozarts og fleiri. ${ }^{3}$

Alpekkt er pýðing Matthíasar Jochumssonar á pessum sálmi: „Dagur reiði, dagur bræði“. Má kalla í senn ofdirfð og óparfa að vinna pað verk að nýju og síst get ég kallað mig jafnoka Matthíasar að bragsnilld. Pað sem pó kom mér af stað, pað er nafn Maríu í 13. erindi. Hann les pað sem nafn Maríu guðsmóður og pýðir: „Dú sem móður pjáđa reistir." Hef ég skilið pað sem vísun til orða Jesú á krossinum til móður sinnar, enda er pað einmitt við krossinn sem María er kölluð „móðirin bjáđa“ - mater dolorosa eins og alpekkt er úr málaralistinni.

Аð pessi skilningur orki tvímælis hafði ég ekki hugsað út í fyrr en einhvern tíma upp úr aldamótum pegar nýjar hugmyndir um Maríu Magdalenu voru komnar í tísku, ekki aðeins meðal guðfræðinga heldur á vîđari menningarvettvangi. Pótt ég læsi mig aldrei verulega inn í pá umræðu hafði ég veður af henni, frétti t.d. að samkvæmt einhverjum af apókrýfu guðspjöllunum (peim sem aldrei voru

1 Niðurlagið (tvö erindi eða a.m.k. fjórar hendingar) kann að vera viðbót eða breyting frá frumtexta. par er ekki aðeins bragurinn frábrugðinn heldur stingur í stúf að skáldið einblínir par ekki á eigin sáluhjálp heldur biður fyrir „manni“ og „peim“.

2 Stafsetning og greinarmerki eru með ýmsu móti í útgáfum. Hér er ritað ae en ekki æ, hins vegar ekki i/u fyrir j/v (nema qu); greinarmerki ekki stranglega samræmd.

3 Pýðingin fylgir stranglega atkvæða- og bragliðaskipan frumtextans. Par með er ekki sagt að hún sé sönghæf. Pýðingu til söngs dugir ekki að gera eftir textanum einum heldur parf að bera hana saman við tónverkið og gæta pess að pagnir og endurtekningar falli eðlilega að textanum. Pegar mörg tónskáld hafa notað sama textann, eins og hér, gæti purft að laga pýðinguna að hverri tónsmío fyrir sig. 
tekin upp í Biblíuna) hefði María Magdalena verið lykilpersóna í lífi Jesú, jafnvel staðið honum nær en sjálfir postularnir. Og einhvern veginn flutu með pær upplýsingar að samkvæmt ritskýringu miðaldakirkjunnar hefði „,bersynduga konan“, sú sem í 7. kapítula Lúkasarguðpjalls laugar fæutur Jesú í tárum, perrar með hári sínu og smyr dýrum smyrslum, verið engin önnur en María Magdalena. ${ }^{4}$

petta hafði ég frétt pegar ég af einhverri rælni skoðaði textann við sálumessu Mozarts, sá par nafn Maríu og að pað sem Jesú gerði fyrir hana hét ekki að „reisa“, eins og hjá Matthíasi, heldur absolvo. Í klassískri latínu getur pað merkt 'leysa úr fjötrum; inna af hendi' og î lagamáli 'sýkna (af ákæru), hreinsa (af grun)' en í máli miðaldakirkjunnar umfram allt 'veita syndaaflausn'. Einkennilegt orðaval um svo syndlausa manneskju sem heilaga guðs móður. En aldeilis upplagt um pá bersyndugu, sem Jesú kvaddi einmitt með peim frægu orðum: „Syndir pínar eru fyrirgefnar.“ Miðaldatextinn hlaut að eiga við Maríu Magdalenu.

Svo ég fór að fikta við að pýða erindið. Allnákvæm pýðing ljóðlínunnar væri: „Maríu lést sýkna saka.“ En íslenskur lesandi eða hlustandi, sem hefði lært sínar biblíusögur líkt og ég, myndi ekki sjá í hendi sér hvaða Maríu átt væri við. Öruggast væri pví að segja pað fullum fetum: „Magdalena sýkn varð saka.“ Utan á petta hlóðst svo pýðingin. Ég hafði ekki hliðsjón af pýðingu Matthíasar, reyndi pvert á móti að muna sem minnst af henni. Vissulega er orðalag víða svipað (t.d. mjög líkt í 15. erindi), en pað held ég stafi oftast af fylgispekt beggja við frumtextann.

Aðrar pýðingar sálmsins pekkti ég ekki né umfjöllun fræðimanna, t.d. Pórhalls Porgeirssonar 1948, en hann greinir frá eldri býðingum

4 Undirrótin að pessari ályktun mun vera sú að í næsta kafla guðspjallsins, par sem María Magdalena er fyrst nefnd á nafn, er hún í hópi kvenna sem styrktu starf Jesú „með fjármunum sínum“ (Lúkas VIII, 3). Af bví má ætla að hún hafi haft nokkur fjárrád, einmitt líkt og bersynduga konan sem hafði efni á dýrum smyrslum. Hjá sumum bættist við sú ágiskun að syndirnar, sem Jesú fyrirgaf, hefou verið tekjulind Maríu, p.e. skækjulifnaður. Að öðru leyti má vísa á pistil sr. Sigurðar Ægissonar í Morgunblađinu 2006: https://www.mbl.is/greinasafn/grein/1094152/. Eins og par kemur fram hafði páfinn sjálfur snemma á miðöldum tekið undir pað að sú bersynduga hefði verið María Magdalena og pað sî̉an verið viðurkennd ritskýring í kapólsku kirkjunni par til hún var opinberlega afturkölluð 1969. En hana hefur Matthías Jochumsson örugglega ekki lært í sinni lútersku guðfræði. Pví má bæta við að pegar kapólska kirkjan dró pað til baka að hin bersynduga hefði verið María Magdalena var texta sekvensunnar breytt úr que Mariam í peccatricem, p.e. „hina syndugu“.

5 „Um pýðingar og endursagnir úr ítölskum miðaldaritum.“ Árbók Landsbókasafns Íslands, bls. 212-224; bls. 220 er bað sem hér skiptir máli. 
Gísla Brynjólfssonar og Helga Hálfdanarsonar (Prestaskólakennara), sömuleiðis bendir hann á endurbirta pýðingu Matthíasar í Kapólskri bcenabók (1922) par sem búið er að leiðrétta Maríuvilluna.

Ekki ætla ég hér að fara yfir pýðinguna frá upphafi til enda, hvorki með samanburði við frumtextann né við aðrar pýðingar, heldur láta nægja nokkur dæmi úr fyrsta erindinu um sígild álitamál bókmenntapýðinga. Og skoða pá, jafnframt textunum hér að ofan, pýðingu Matthíasar:

\section{Dagur reiði, dagur bræði drekkir jörð í logaflæði, votta heilög völufræði.}

Fyrsta ljóðlína latínutextans er orðrétt biblíutilvitnun. Pað er einn af smærri spámönnunum, Sefanía (eða Sófonías), sem er aðalfyrirmynd sálmsins og segir hann (í 1. kapítula, 15. versi): „Dagur reiði verður dagur sá." “ Tilvitnanir eru auðvitað eitt hinna frægu fótakefla býðenda. Hér leyfir bragurinn ekki að halda íslenska biblíutextanum orðréttum og fáir íslenskir lesendur munu svo kunnugir pessum ritningarstað’ að pekkjanleg orðalagslíkindi pjóni nokkrum tilgangi. Reyndar býst ég við að pað sama hafi átt við um viðtakendur latínutextans. Hann hefur fljótt orðið svo miklu pekktari en spádómsbók Sefanía að dies irae, dies illa hefur í huga fólks orðið að tilvitnun í sálminn, ekki Gamla testamentið.

раð virðist pannig óparfi að pýða endilega dies illa ('dagur sá) enda gerum við Matthías pað hvorugur. Hann notar í staðinn tvöfalda pýðingu á dies irae, p.e. „Dagur reiði, dagur bræði“ og heldur nefnifalli latínunnar svo að dagurinn verður gerandi bess sem í næstu línu segir. Ég hef hrakist lengra frá frumtexta, segi „heiftardaginn“ (í tímapolfalli) og fylli seinni bragliðina með efni sem ekki á sér samsvörun á latínunni: „hinst á láði“. Vissulega snýst kvæðið allt um hinn efsta dag, pann sîđasta í sögu jarðarinnar, svo að pessi orð gæetu

6 Svo í Biblíu 21. aldar. „Sá dagur er dagur reiðinnar, “ hefur pað verið í Biblíu Matthíasar en í minni: „Sá dagur er dagur reiði.“

7 Pótt Grímur meðhjálpari î Manni og konu sé reyndar svo biblíufastur að vitna til Sófoníusar spámanns um „dag grimmdarinnar“. 
átt par heima en eru par ekki frá höfundarins hendi. Svipaðar uppfyllingar frá eigin brjósti koma fyrir allvíoa í býðingunni par sem mig brast hagmælsku til að fella eiginlega pýðingu að formi bragarins. Lakast er pað víst í 16. erindi par sem einungis orðin „fordæmdir“, „logum“ og „kalla mig“ eru raunveruleg býðing, hitt allt hallærislausnir í bragnaud.

Að pýða orðin dies illa virðist sem sagt óparft - pegar aðeins er horft á fyrsta erindið. En svo kemur í ljós að pau enduróma í erindum 9 (illa die - hér hefur latínan tíoarfall eins og ég notaði í upphafsorðunum) og 18 (aftur dies illa). Pessi endurtekning skilar sér aðeins að hluta í býðingu minni par sem „hinsta dag“ í níunda erindi á að kallast á vio „hinst á láoi“ í pví fyrsta.

Að dies irae sé „dagur reiði“ er einfalt mál, orðrétt býðing eins og í Biblíunni. En „dagur brceði“ hjá Matthíasi, hvað pá „,heiftardagur“ hjá mér, par er öllu meira í lagt. „Bræði“ eða „heift“ táknar helst stjórnlausa geðshræringu, sídur pá réttmætu og yfirveguðu reiði sem hæfa myndi almáttugum Guði. (Pó að í sjálfum Passíusálmunum segi reyndar: „Drottins tími pá tekur af / tvímælin öll í brceði.“) Í Biblíu 21. aldar er Sefanía (I, 18) látinn segja: „Á reiðidegi Drottins og í heiftarbáli hans verður öllu landinu eytt.“ Hér heitir pað „heift“ Guðs sem eldri pýðingar kalla „vandlætingu“, á latínu zelus. Síðar (III, 8) lætur Sefanía Drottin hóta konungsríkjum heims „að ausa yfir pau reiði minni, allri minni logandi beift. Já, fyrir eldi brceði minnar mun öll jörðin eyðast.“ Hér hefur latneska Biblían (Vulgata) indignatio og furor, orð sem tákna a.m.k. ekkert jafnaðargeð, og er pá ekki fráleitt að höfundur sálmsins hafi talið sams konar reiði birtast í peim orðum sem hann tók upp sem fyrstu ljóđlínu.

Látum pá útræett um hana.

Í annarri hendingu segir hvað dagur reiðinnar gerir - „drekkir jörð í logaflæði“ hjá Matthíasi - eða, hjá mér, hvað gerist pann dag - „heimur ferst í sindurs flóði“. „Jörð“ eða „heimur“ er einfölduð býoing á lat. saec(u)lum, sem m.a. merkir ‘öld, tímabil' en líka ‘tíminn sjálfur' og par með 'hið tímanlega, veröldin'. Sögnin, solvo, merkir aðallega 'leysa' en líka '(um efni eða hluti) leysa sundur, leysa upp, láta bráđna eða gufa upp’. Hin tímanlega veröld á pannig að leysast sundur in favilla, p.e. verða að 'glóðum, neistum, heitri ösku eða gjalli’ (m.a. notað um „ösku“ látins manns og pá átt við glóðina eftir 
líkbrennslu). Eldur eða bruni er ekki nefndur í pessu sambandi (eldur helvítis í 14. erindi er annað mál) en liggur í samhenginu. Báðar pýðingarnar gefa í skyn að eldurinn sé jarðeldur. „Logaflæði“ Matthíasar, sem „drekkir“ jörðinni, hlýtur að minna íslenska viðtakendur á flæðigos. Pó að „sindur“ sé ekki beinlínis hraun heldur neistar eða heitt gjall frá járnvinnslu og „sindurs flóð“ eiginlega flóð af glóandi gjalli - eins og í Snorra-Eddu: ,sem sindur pað er renn úr eldinum“ - pá er varla hægt að skilja pað heldur sem annað en líkingu fyrir glóandi hraun. Hér höfum við pá, báđir pýðendurnir, freistast til að koma til móts við okkar sérstaka lesendahóp með líkingu sem ekki felst í frumtextanum. Er pó ævinlega álitamál hve langt megi ganga í pví efni.

Hliðstæðri freistingu hef ég fallið fyrir í níunda erindi par sem skáldið biður Jesú vissulega að minnast sín, en ég hef pýtt pað með auðpekktu orðalagi Passíusálmanna („Hafðu, Jesú, mig í minni“). Óbeinni vísun felst í pýðingu fjórða erindis par sem dauðinn „glúpnar, dignar, stríðir“ - með premur orðum par sem latínan hefur eitt, en slíkar orðaprennur skynja ég sem vörumerki Hallgríms Péturssonar („Bið, styn, andvarpa“ og fjölmargt pví um líkt). Passíusálmarnir eru, líkt og jarðeldurinn, séríslenskur veruleiki sem spyrja má hvaða erindi eigi inn í pýðingu á ítölskum miðaldatexta.

Priðja hendingin er svo eins konar tilvísun og heimildirnar tvær: Davíd og „Sibylla“.

Matthías pýðir: „votta heilög völufræði“; gerir sér lítið fyrir og sleppir Davíð. Рað kann að virðast nokkurt gjörræði af pýðanda. Pess ber pó að gæta að pekkjanlegar fyrirmyndir kvæðisins eru fyrst og fremst hjá Sefanía, sumt á hliðstæður í öđrum spádómsbókum Biblíunnar, jafnvel í guðspjöllunum (eins og hafrar og sauðir í 15. erindi), en líkindi við Davîđssálma eru fá og býsna óljós. Hér kann pví að „vakna sú spurning hvort mikils sé misst“ pó að nafn Davîos falli niður.

„Völufræði“ Matthíasar er, pegar að er gád, merkilega nákvæm pýding á Sibyllu sálmsins. Hinar upphaflegu „síbyllur“ voru spágyðjur Forngrikkja sem áttu að hafa pjónað við tiltekna helgidóma par sem pær mæltu fram goðsvör véfrétta. Hafa pær að miklu leyti verið pjóðsagnapersónur, sumar sagðar goðkynjaðar, en pó kunna raunverulegar konur að hafa brugðið sér í petta hlutverk. Rómverjar 
töldu sig vita deili á einum tíu síbyllum og koma pær, eins og fleira úr rómverskri menningu, víða fyrir í myndlist endurreisnartímans. En fyrr á miðöldum höfðu pær einkum verið pekktar af spádómasafni, Oracula sibyllina, sem gekk í handritum í ýmsum tilbrigðum. Efnið var af fjölbreyttum uppruna, mest aftan úr heiðni en sumt lagfært eða aukið við af gyðingum og kristnum. Kristnir guðfræðingar tóku petta safn gilt sem ævaforn goðsvör heiðinna hofgyðja og töldu sig sjá í pví stórmerkilegar hliðstæður við spádóma Biblíunnar, svo sem um komu lausnarans og ekki síst um dómsdag. Einmitt pá spádóma hlýtur höfundur sálmsins að eiga við. Hann nefnir Davío sem eins konar fulltrúa Gamla testamentisins og sams konar persónugervingur Oracula-safnsins ber hjá honum sérnafnið Sibylla. Рað hafði nefnilega rutt sér til rúms sem kvenmannsnafn, m.a. í furstaættum 12. og 13. aldar. (Á uppvaxtarárum Tómasar frá Celano höfou konur með pví nafni t.d. verið drottningar á Sikiley, í Armeníu og í krossfararíkinu Jerúsalem.) Má af pví ráđa í hve jákvæðu ljósi menn sáu hinar fornu spágyðjur. Sjálfur veit Tómas auðvitað af Nýja testamentinu (Opinberunarbókinni) hvers vænta megi á efsta degi en hann vill benda á hvernig hin fornu helgirit höfðu spáo pví sama og leggur hann par síbylluspárnar að jöfnu við sjálft Gamla testamentið.

Að kalla pessi Oracula sibyllina „,ölufræði“ á íslensku hittir pannig vissulega í mark ef hugsað er út frá merkingarheimi frumtextans. Og „heilög“ að auki, sem að vissu leyti gerir sama gagn og tengingin við Davíð í frumtextanum. Gallinn er sá að lesandi eins og ég, sem ekki pekkti til samhengisins, gat svo hæglega misskilið, fundist að Matthías væri hér að staðfæra og hlyti að meina eddukvæðið Völuspá; kvæði sem líka flytur spádóm um heimsslit, einmitt í eldi - „Surtarloga“ sem Snorra-Edda kallar - par sem „leikur hár hiti / við himin sjálfan“, pví líkast sem lýst sé íslensku eldgosi. Mitt orðalag: „dís með Davíð“, býður ekki heim neinni slíkri tengingu en er hins vegar bragðdauft og skilar engu af peirri merkingu sem hámiðaldir lögðu í síbylluspárnar.

Pá er órætt eitt orð latínutextans, teste, af testis sem aðallega merkir 'vitni (fyrir rétti), sjónarvottur'. Pað er pví betur býtt sem „votta“ en „spáði“. Mér kom reyndar á óvart, pegar ég fór að rýna í latínutextann, hve hlaðinn hann er lögfræðilegu orðfæri. Ekki aðeins um „dóm“ og „dómara“ heldur sérhæfðari hugtök, eins og reus (tvisvar), 
p.e. 'sakborningur'. Ég náđi pessu ekki alltaf á íslenskunni, t.d. ekki parna í fyrsta erindi, og reyndi pá að bæta pað upp með lagamáli eins og að „taka sáttum“ í 13. erindi eða „,dómsáfelli“ i i 12. erindi, par sem latínan nefnir aðeins 'kinnroða'. Hér reynir á enn eitt álitamál pýðingarfræðanna, p.e. hvort frávik í gagnstæðar áttir bæti hvort annað upp og megi pannig koma einkennum frumtextans til skila pótt pað sé ekki endilega á réttum stöðum.

Allt er petta um fyrstu prjár hendingarnar, pó aðeins bornar saman tvær af fjórum íslenskum pýðingum sálmsins, og „mundi dýr Hafliði allur“ ef reynt væri að tæma umræðuefnið. Skal pví hér bundinn endi að sinni. 